\title{
PENERAPAN MODEL DT2 (DUA TINGGAL DUA TAMU) DALAM MENINGKATKAN HASIL BELAJAR SOSIOLOGI MELALUI AKTIVITAS GURU DAN SISWA KELAS XI SMA NEGERI 12 MAKASSAR
}

\author{
AKHIRUDDIN, ROSNATANG \\ akhiruddinudin@ymail.com, rosnatang89@gmail.com \\ DOSEN STKIP MEGA REZKY MAKASSAR
}

\begin{abstract}
Implementation of DT2 (two stay-two guests) model in increasing of sociology learning achievement through the activities of teachers and students of XI grade students of SMA 12 Makassar.

This research aimed to know to increase sociology learning achievement through the activities of teachers and students of XI grade students of SMA 12 Makassar.It was classroom action research (CAR) by using two cycles. Each cycles were consisted four stages, they were planning, action, observation and reflection. Subject of research was XI grade students of SMA 12 Makassar in academic year 2017/2018 with the number of students was 32, they were consisted of 15 male students and 17 female students. Data collection used observation and data of students' achievement learning test. Data analaysis technique was test, it was analyzed by using score based on benchmark reference assessment, it was calculated based on the maximum score that it will be achieved by students.

Based on result of research had been obtained from XI grade students of SMA 12 Makassar showed that the improvement of learning is maximized by the teacher so that learning takes place well. For cycle II has succed in reaching target with percentage of students learning outcomes can increase from cycle I only reached $62.50 \%$ with sufficient qualifications increased to be $96.87 \%$ with excellent qualifications in cycle II.
\end{abstract}

Keywords: DT2 (Two Stay-Two Guests) Model, Sociology Learning Achievement

\section{A. PENDAHULUAN}

\section{Latar Belakang}

Pendidikan merupakan suatu kegiatan yang universal di dalam kehidupan manusia, untuk memanusiakan manusia itu sendiri, yaitu manusia berbudaya. Karena untuk membangun manusia yang berkualitas maka syarat utama yang harus di perhatikan adalah mutu pendidikan yang berkualitas serta sistem yang relevan dengan mutu yang ingin dicapai sesuai tujuan pendidikan nasional

Tujuan pendidikan yang tercantum dalam pembukaan Undang-Undang Dasar 1945, dimana tujuan tersebut adalah mencerdaskan kehidupan bangsa, mengembangkan 
manusia Indonesia seutuhnya. Maka salah satu upaya yang dilakukan adalah bagaimana seorang guru mampu melakukan variasi dalam pembelajaran seperti masalah pendekatan moral, keteladanan dan model dalam pembelajaran.

Mengingat pentingnya model dalam pembelajaran, di mana model pembelajaran diartikan sebagai suatu kegiatan pembelajaran yang harus dikerjakan guru dan siswa agar tujuan pembelajaran dapat dicapai secara afektif dan efisien, maka seorang guru dituntut untuk memahami berbagai macam pendekatan dan model pembelajaran.

Salah satu model pembelajaran yang dapat digunakan untuk mengatasi masalah yang telah teridentifikasi adalah menggunakan model pembelajaran aktif (cooperative learning) lebih mendorong siswa aktif dalam proses pembelajaran. Bahwa model pembelajaran kooperatif tipe DT2 (Dua Tinggal Dua Tamu) dapat mendorong siswa untuk mengamati atau melakukan observasi selama proses pembelajaran, menerapkan konsep atau prinsip, interprestasi, mengkomunikasikan hasil permasalahan baik secara lisan maupun tulisan, dapat dengan mudah mengajukan pertanyaan serta menciptakan suasana yang menyenangkan.

Hasil pengamatan yang dilakukan penulis di kelas XI SMA Negeri 12 Makassar, yaitu hasil belajar sosiologi masih dalam kategori rendah sesuai dengan KKM yakni 70. Ada beberapa permasalahan yang dihadapi siswa dalam pembelajaran sosiologi di SMA Negeri 12 Makassar. Pertama, berdasarkan hasil pengamatan penulis, selama ini para siswa cenderung menganggap mata pelajaran sosiologi merupakan mata pelajaran yang tidak terlalu penting untuk dipelajari, keberadaannya di hati siswa masih menjadi nomor kesekian di banding pelajaran lain yang di anggap penting dan sangat fundamental, seperti Matematika, Bahasa Inggris, Bahasa Indonesia dan beberapa pelajaran yang lain. Kedua, akibat pemahaman yang keliru di atas mengakibatkan siswa kurang termotivasi mempelajari lebih dalam mata pelajaran sosiologi, sehingga berimplikasi kepada hasil belajar sosiologi yang masih tergolong rendah.

\section{Rumusan Masalah}

Adapun rumusan masalah yaitu bagaimana penerapan model pembelajaran DT2 (Dua Tinggal Dua Tamu) untuk meningkatkan hasil belajar Sosiologi kelas XI SMA Negeri 12 Makassar? 


\section{Metode Penelitian}

a) Jenis Penelitian

Penelitian ini merupakan penelitian tindakan kelas (PTK). Secara singkat penelitian tindakan kelas dapat di defenisikan sebagai proses pengkajian dari berbagai kegiatan pembelajaran, dilakukan melalui empat (4) tahapan yang meliputi: perencanaan, pelaksanaan tindakan, pengamatan/pengumpulan data, dan refleksi.

b) Subjek penelitian

Subjek dari penelitian ini adalah siswa kelas XI SMA Negeri 12 Makassar pada tahun 2018 dengan jumlah siswa 32 orang

c) Prosedur Penelitian.

Prosedur penelitian tindakan kelas ini menggunakan model Kemmis dan Mc. Taggar yang dijabarkan sebagai berikut.

Siklus I

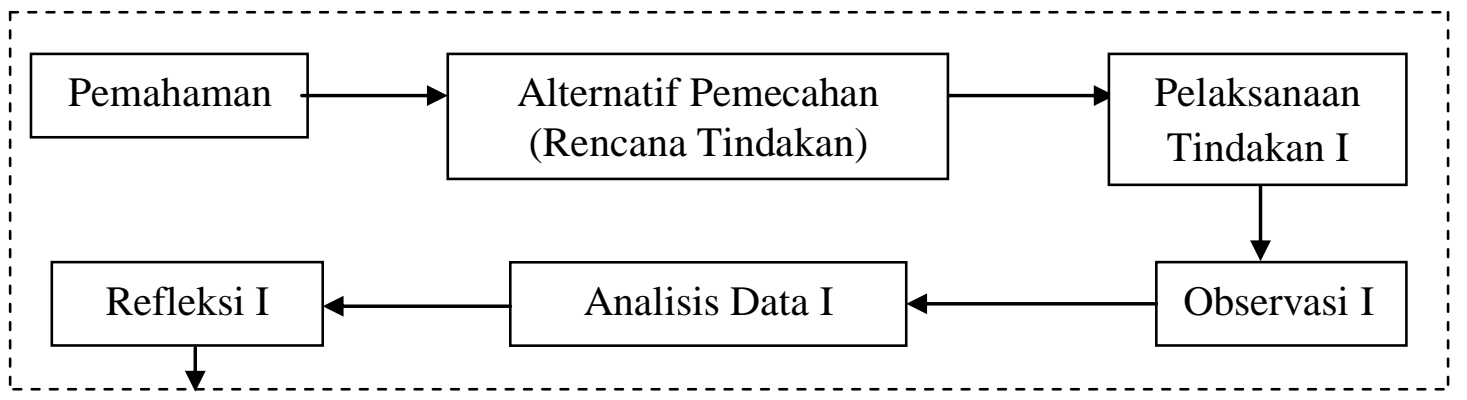

Siklus II

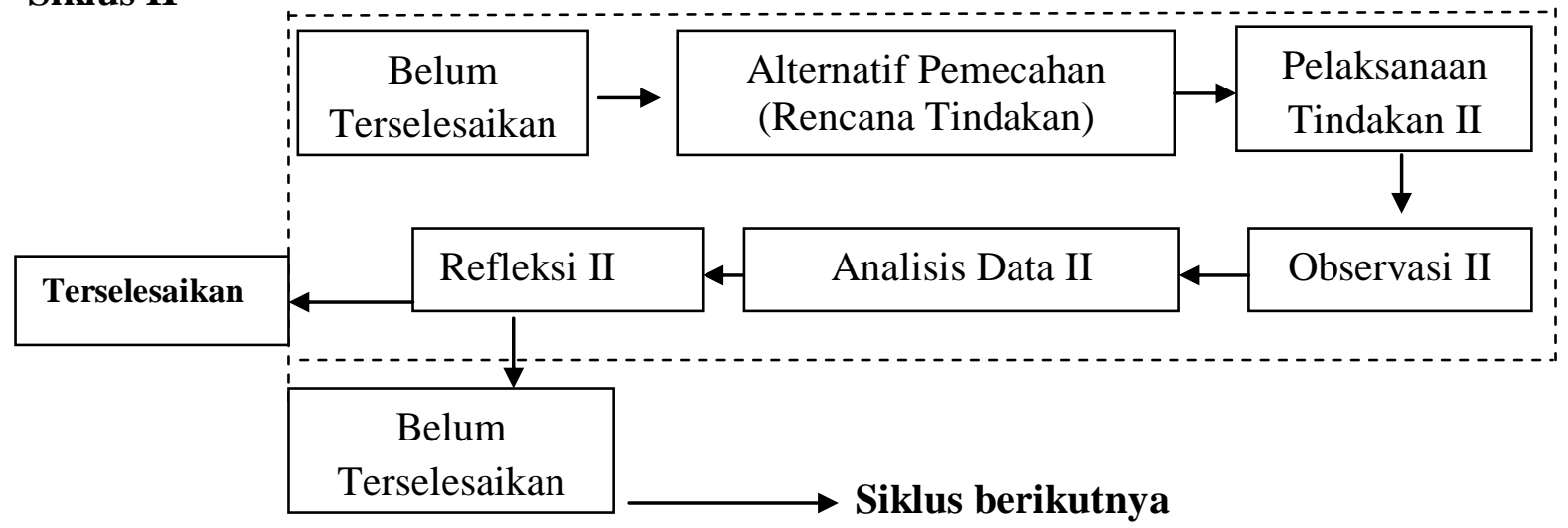

d) Teknik Pengumpulan Data

(1) Observasi: Data tentang kondisi proses belajar mengajar selama tindakan dilakukan diambil dengan menggunakan observasi baik secara langsung dan tidak langsung dengan beberapa indikator yang diamati. (2) Data tes hasil 
belajar: Tes berbentuk Pilihan Ganda \& Essay digunakan untuk mengambil data pada siklus I dan siklus II

e) Teknik Analisis Data

Data hasil belajar siswa berupa tes akan dianalisis dengan menggunakan skor yang berdasarkan penilaian acuan patokan, dihitung berdasarkan skor maksimal yang mungkin dicapai oleh siswa. Kriteria yang digunakan untuk menentukan kategori hasil belajar sosiologi adalah berdasarkan teknik kategorisasi yang ditetapkan oleh Departemen Pendidikan Nasional (Mardia, 2004: 20).

\section{B. KAJIAN PUSTAKA}

\section{Pembelajaran Sosiologi}

Pembelajaran sosiologi merupakan interaksi antara siswa dengan komponen lainya. Dalam keseluruhan proses pendidikan, kegiatan belajar mengajar merupakan kegiatan yang paling pokok. Setiap kegiatan pembelajaran sosiologi selalu melibatkan dua pelaku aktif, yaitu guru dan siswa. Guru sebagai pengajar merupakan pencipta kondisi belajar siswa yang di desain secara sengaja, sistematis dan berkesinambungan. Sedangkan anak sebagai subyek pembelajaran merupakan pihak yang menikmati kondisi belajar yang diciptakan guru.

Sebagai ilmu pengetahuan, sosiologi dapat diartikan sebagai suatu ilmu pengetahuan yang mempunyai objek studi masyarakat. Menurut Roucek and Warren dalam (Abdulsyani, 2007: 5), mengemukakan bahwa sosiologi adalah ilmu yang mempelajari hubungan antar manusia dan kelompok. Bertujuan suatu cita-cita yang ingin dicapai dalam pelaksanaan pembelajaran. Dalam pendidikan pembelajaran sosiologi merupakan suatu cita-cita bernilai normatif. Sebab dalam tujuan terdapat sejumlah nilai yang harus ditanamkan kepada anak didik. Nilai-nilai itu nantinya akan mewarnai cara anak didik bersikap dan berbuat dalam lingkungan sosial baik di sekolah maupun di kelas. Pembelajaran sosiologi disekolah menengah berfungsi untuk meningkatkan kemampuan siswa mengaktualisasikan potensi-potensi diri mereka dalam mengambil dan mengungkapkan status dan peran masing-masing dalam kehidupan sosial dan budaya yang terus mengalami perubahan. 


\section{Hasil Belajar}

Sasaran dari kegiatan belajar adalah hasil belajar. Apabila proses belajar berjalan dengan baik, maka hasil belajar juga akan baik pula. Menurut Hamalik (2008: 30) mengatakan "Bukti bahwa seseorang telah belajar ialah terjadinya perubahan tingkah laku pada orang tersebut, misalnya dari tidak tahu menjadi tahu, dan dari tidak mengerti menjadi mengerti. Tingkah laku memiliki unsur subjektif dan unsur motoris. Unsur subjektif adalah unsur rohaniah sedangkan unsur motoris adalah unsur jasmaniah”.

Hasil belajar adalah kemampuan yang diperoleh anak dari suatu interaksi dalam proses pembelajaran. Hasil belajar dapat juga diartikan sebagai hasil akhir pengambilan keputusan mengenai tinggi rendahnya nilai yang diperoleh siswa selama mengikuti proses pembelajaran. Hasil belajar dikatakan tinggi apabila tingkat kemampuan siswa bertambah dari hasil sebelumnya. Hasil belajar sering digunakan dalam arti yang sangat luas yakni untuk bermacam-macam aturan terhadap apa yang telah dicapai oleh siswa, misalnya ulangan harian, tugas-tugas pekerjaan rumah, tes lisan yang dilakukan selama pelajaran berlangsung, tes akhir semester dan sebagainya. Dalam penelitian ini, hasil belajar yang dimaksudkan adalah hasil tes tiap siklus.

\section{Model DT2 (Dua Tinggal Dua Tamu)}

Salah satu model pembelajaran kooperatif adalah model "Dua tinggal dua tamu (DT2)". Pembelajaran kooperatif model DT2 yang memberikan kesempatan kepada kelompok membagikan hasil dan informasi kepada kelompok lain. Hal ini dilakukan karena banyak kegiatan belajar mengajar yang diwarnai dengan kegiatan-kegiatan individu. Siswa bekerja sendiri dan tidak diperbolehkan melihat pekerjaan siswa yang lain. Padahal dalam kenyataan hidup di luar sekolah, kehidupan dan kerja manusia saling bergantung satu sama lainnya. Metode ini juga melatih siswa untuk bersosialisasi dengan baik (Huda, 2014: 17).

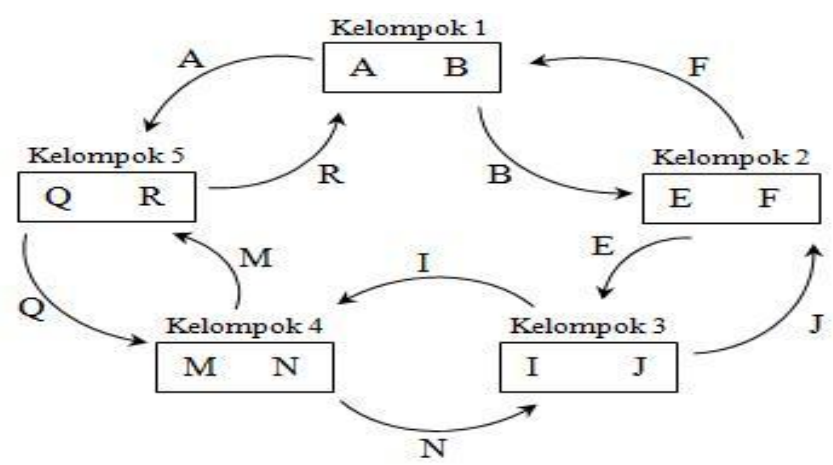


Model pembelajaran Dua Tinggal Dua Tamu bisa memberikan sedikit gambaran pada siswa mengenai kenyatan kehidupan di masyarakat, yaitu dalam hidup bermasyarakat diperlukan hubungan ketergantungan dan interaksi sosial antara individu dengan individu lain dan antar individu dengan kelompok. Penggunaan model pembelajaran dua tinggal dua tamu akan mengarahkan siswa untuk aktif, baik dalam berdiskusi, tanya jawab, mencari jawaban, menjelaskan dan juga menyimak materi yang dijelaskan oleh teman. Selain itu, alasan menggunakan model dua tinggal dua tamu ini karena terdapat pembagian kerja kelompok yang jelas tiap kelompok, siswa dapat bekerja sama dengan temannya, dapat mengatasi kondisi siswa yang ramai dan sulit diatur saat proses belajar mengajar.

\section{HASIL PENELITIAN}

Pada bab ini dibahas tentang hasil-hasil penelitian setelah pelaksanaan Model Pembelajaran DT2 pada siswa kelas XI SMAN 12 Makassar. Hasil penelitian tindakan kelas yang telah dilaksanakan meliputi hasil observasi dan tes siklus I, hasil tes siklus II.

\section{HASIL TES SIKLUS I}

Pembelajaran sosiologi di kelas XI SMA Negeri 12 Makassar berkaitan dengan pelaksanaan pembelajaran sesuai dengan tahap-tahap model pembelajaran DT2 yang telah disusun. Pada pembelajaran siklus I tentang pelaksanaan kegiatan pembelajaran yang berlangsung sesuai dengan yang telah disusun ternyata belum terlaksana secara maksimal. Hasil observasi pelaksanaan pembelajaran siklus I adalah sebagai berikut.

\section{a) Kegiatan Mengajar Guru}

Hasil observasi kegiatan mengajar guru adalah seperti yang ada dalam tabel berikut.

Hasil Observasi Kegiatan Mengajar Guru

\begin{tabular}{|c|c|c|c|c|c|c|}
\hline \multirow{2}{*}{ Indikator } & \multicolumn{6}{|c|}{ Siklus I } \\
\cline { 2 - 7 } & \multicolumn{2}{|c|}{ Pertemuan 1 } & \multicolumn{2}{c|}{ Pertemuan 2 } & \multicolumn{2}{c|}{ Pertemuan 3 } \\
\hline Sangat Baik (5) & 2 & 10 & 2 & 10 & 3 & 15 \\
\hline Baik (4) & 2 & 8 & 2 & 8 & 3 & 12 \\
\hline Cukup (3) & 4 & 12 & 6 & 18 & 6 & 18 \\
\hline Kurang (2) & 7 & 14 & 5 & 10 & 3 & 6 \\
\hline Sangat Kurang (1) & 0 & 0 & 0 & 0 & 0 & 0 \\
\hline Total Perolehan Skor & $\mathbf{1 5}$ & $\mathbf{4 4}$ & $\mathbf{1 5}$ & $\mathbf{4 6}$ & $\mathbf{1 5}$ & $\mathbf{5 1}$ \\
\hline Persentase & \multicolumn{2}{|c|}{$\mathbf{5 8 , 6 7 \%}$} & \multicolumn{6}{|c|}{$\mathbf{6 1 , 3 3 \%}$} & $\mathbf{6 8 , 0 0 \%}$ \\
\hline
\end{tabular}

Sumber: Hasil Observasi Siklus I 
Berdasarkan hasil observasi kegiatan mengajar guru diatas pada siklus I ratarata secara keseluruhan diperoleh 47 dari $75(62,67 \%)$ termasuk dalam kualifikasi cukup.

\section{b) Kegiatan Siswa}

Hasil observasi kegiatan belajar siswa pada tabel dibawah ini yaitu

\begin{tabular}{|c|c|c|c|c|c|c|}
\hline \multicolumn{7}{|c|}{ Hasil Observasi Kegiatan Belajar Siswa } \\
\hline \multirow{2}{*}{ Indikator } & \multicolumn{6}{|c|}{ Siklus I } \\
\hline & \multicolumn{2}{|c|}{ Pertemuan 1} & \multicolumn{2}{|c|}{ Pertemuan 2} & \multicolumn{2}{|c|}{ Pertemuan 3} \\
\hline Sangat Baik (5) & 1 & 5 & 2 & 10 & 3 & 15 \\
\hline Baik (4) & 1 & 4 & 2 & 8 & 2 & 8 \\
\hline Cukup (3) & 7 & 21 & 5 & 15 & 7 & 21 \\
\hline Kurang (2) & 6 & 12 & 6 & 12 & 3 & 6 \\
\hline Sangat Kurang (1) & 0 & 0 & 0 & 0 & 0 & 0 \\
\hline Total Perolehan Skor & 15 & 42 & 15 & 45 & 15 & 50 \\
\hline Persentase & \multicolumn{2}{|c|}{$56,00 \%$} & \multicolumn{2}{|c|}{$60,00 \%$} & \multicolumn{2}{|c|}{$66,67 \%$} \\
\hline
\end{tabular}

Sumber: Hasil Observasi Siklus I

Berdasarkan hasil observasi kegiatan belajar siswa diatas pada siklus I secara keseluruhan diperoleh 45,67 dari 75 (60,89\%) termasuk dalam kualifikasi cukup.

\section{c) Hasil Tes Belajar Siklus I}

Data tentang hasil belajar siswa pada siklus I digunakan untuk mengetahui nilai hasil belajar siswa setelah kegiatan tindakan siklus I dengan melakukan evaluasi terhadap siswa. Berdasarkan hasil evaluasi diperoleh data sebagai berikut.

\section{Perolehan Nilai Siswa Siklus I}

\begin{tabular}{|c|c|c|}
\hline No & Kategori & Nilai \\
\hline 1 & Mean & 69,38 \\
\hline 2 & Median & 70 \\
\hline 3 & Modus & 75 \\
\hline 4 & Nilai Terendah & 60 \\
\hline 5 & Nilai Tertinggi & 75 \\
\hline
\end{tabular}

Sumber : Hasil Evaluasi Siswa Siklus I

Berdasarkan tabel diatas, perhitungan hasil belajar siklus I menunjukkan bahwa nilai rata-rata hasil belajar siswa sebesar 69,38 dapat dikatakan berada pada kategori cukup.

Distribusi Frekuensi Dan Persentase Hasil Belajar Siswa Siklus I

\begin{tabular}{|c|c|c|c|}
\hline Interval Nilai & Frekuensi (f) & Persen $(\boldsymbol{\&})$ & Kategori \\
\hline $0-40$ & 0 & 0 & Sangat Kurang \\
\hline $41-55$ & 0 & 0 & Kurang \\
\hline $56-70$ & 20 & 62,50 & Cukup \\
\hline
\end{tabular}




\begin{tabular}{|c|c|c|c|}
\hline $71-85$ & 12 & 37,50 & Baik \\
\hline $86-100$ & 0 & 0 & Sangat Baik \\
\hline Jumlah & $\mathbf{3 2}$ & $\mathbf{1 0 0 \%}$ & \\
\hline
\end{tabular}

Sumber: Hasil Evaluasi Siswa Siklus I

Diagram Batang Distribusi Frekuensi Dan Persentase Hasil Belajar Siswa Siklus I

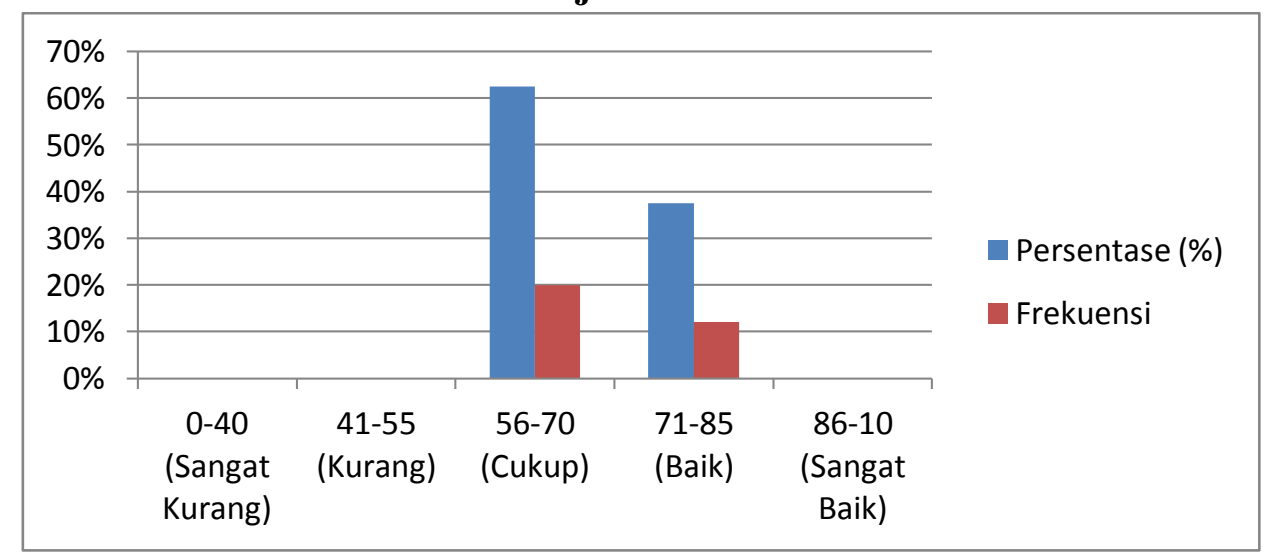

Berdasarkan tabel dan diagram diatas diketahui bahwa tidak ada siswa yang mempunyai nilai dengan kategori sangat kurang, kurang dan sangat baik, 20 siswa $(62,50 \%)$ berada pada kategori cukup dan 12 siswa $(37,50 \%)$ berada pada kategori baik. Jadi dapat dikatakan rata-rata hasil belajar siswa XI SMA Negeri 12 Makassar berada pada ketegori cukup kategori kurang pada siklus I.

Ketuntasan Belajar Siswa Siklus I

\begin{tabular}{|c|c|c|c|}
\hline Skor & Katergori & Frekuensi & Persentase (\%) \\
\hline $0-69$ & Tidak Tuntas & 12 & $37.5 \%$ \\
\hline $70-100$ & Tuntas & 20 & $62.5 \%$ \\
\hline \multicolumn{2}{|r|}{ Jumlah } & $\mathbf{3 2}$ & $\mathbf{1 0 0}$ \\
\hline
\end{tabular}

Berdasarkan tabel di atas, tentang ketuntasan hasil belajar menunjukkan bahwa 12 siswa yang mendapatkan nilai 0-69 dengan persentase 37.5\% yang tidak tuntas dan sedangkan 20 siswa yang mendapatkan nilai 70-100 dengan persentase $63.5 \%$ yang tuntas. Olehnya itu, guru memberikan arahan kepada siswa untuk lebih mempersiapkan diri dalam mengikuti proses pembelajaran, diadakan tindakan lanjut yaitu pada siklus II.

Berdasarkan analisis dan refleksi di atas dengan mengacu pada indikator keberhasilan dan kriteria ketuntasan secara klasikal yang telah ditetapkan peneliti, maka dapat disimpulkan bahwa proses belajar sosiologi dengan menerapkan model 
pembelajaran DT2 siswa kelas XI pada tindakan siklus I belum berhasil, maka perlu dilaksanakan siklus II.

\section{HASIL TES SIKLUS II}

Pembelajaran sosiologi di kelas XI SMA Negeri 12 Makassar berkaitan dengan pelaksanaan pembelajaran sesuai dengan tahap-tahap model pembelajaran DT2 yang telah disusun. Pada pembelajaran siklus II tentang pelaksanaan kegiatan pembelajaran yang berlangsung sesuai dengan yang telah disusun ternyata terlaksana dengan maksimal. Berdasarkan hasil observasi menunjukkan bahwa pelaksanaan kegiatan pembelajaran mengalami peningkatan dari hasil observasi pelaksanaan kegiatan pembelajaran pada siklus I. Hasil observasi pelaksanaan pembelajaran siklus II adalah sebagai berikut.

\section{a) Kegiatan Mengajar Guru}

Hasil observasi kegiatan mengajar guru adalah seperti yang ada dalam tabel berikut.

\section{Hasil Observasi Kegiatan Mengajar Guru}

\begin{tabular}{|c|c|c|c|c|c|c|}
\hline \multirow{2}{*}{ Indikator } & \multicolumn{7}{|c|}{ Siklus II } \\
\cline { 2 - 7 } & Pertemuan 1 & \multicolumn{2}{|c|}{ Pertemuan 2 } & \multicolumn{2}{c|}{ Pertemuan 3 } \\
\hline Sangat Baik (5) & 4 & 20 & 5 & 25 & 7 & 35 \\
\hline Baik (4) & 4 & 16 & 6 & 24 & 7 & 28 \\
\hline Cukup (3) & 4 & 12 & 4 & 12 & 1 & 3 \\
\hline Kurang (2) & 3 & 6 & 0 & 0 & 0 & 0 \\
\hline Sangat Kurang (1) & 0 & 0 & 0 & 0 & 0 & 0 \\
\hline Total Perolehan Skor & $\mathbf{1 5}$ & $\mathbf{5 4}$ & $\mathbf{1 5}$ & $\mathbf{6 1}$ & $\mathbf{1 5}$ & $\mathbf{6 6}$ \\
\hline Persentase & $\mathbf{7 2 , 0 0 \%}$ & $\mathbf{8 1 , 3 3 \%}$ & $\mathbf{8 8 , 0 0 \%}$ \\
\hline
\end{tabular}

Sumber: Hasil Observasi Siklus II

Berdasarkan hasil observasi kegiatan mengajar guru diatas pada siklus II ratarata secara keseluruhan diperoleh 60,33 dari $75(80,44 \%)$ termasuk dalam kualifikasi baik.

\section{b) Kegiatan Siswa}

Hasil observasi kegiatan belajar siswa adalah seperti yang ada dalam tabel berikut.

\section{Hasil Observasi Kegiatan Belajar Siswa}

\begin{tabular}{|c|c|c|c|c|c|c|}
\hline \multirow{2}{*}{ Indikator } & \multicolumn{5}{|c|}{ Siklus II } \\
\cline { 2 - 7 } & \multicolumn{2}{|c|}{ Pertemuan 1 } & \multicolumn{2}{c|}{ Pertemuan 2 } & \multicolumn{2}{c|}{ Pertemuan 3 } \\
\hline Sangat Baik (5) & 4 & 20 & 4 & 20 & 6 & 30 \\
\hline Baik (4) & 3 & 12 & 7 & 28 & 8 & 32 \\
\hline Cukup (3) & 7 & 21 & 4 & 12 & 1 & 3 \\
\hline
\end{tabular}




\begin{tabular}{|c|c|c|c|c|c|c|}
\hline Kurang (2) & 1 & 2 & 0 & 0 & 0 & 0 \\
\hline Sangat Kurang (1) & 0 & 0 & 0 & 0 & 0 & 0 \\
\hline Total Perolehan Skor & 15 & 55 & 15 & 60 & 15 & 65 \\
\hline Persentase & \multicolumn{2}{|c|}{$73,33 \%$} & \multicolumn{2}{|c|}{$80,00 \%$} & \multicolumn{2}{|c|}{$86,67 \%$} \\
\hline
\end{tabular}

Sumber: Hasil Observasi Siklus II

Berdasarkan hasil observasi kegiatan belajar siswa diatas pada siklus II secara keseluruhan diperoleh 60,00 dari 75 (80,00\%) termasuk dalam kualifikasi baik

\section{c) Hasil Tes Belajar Siklus II}

Data tentang hasil belajar siswa pada siklus II digunakan untuk mengetahui peningkatan nilai siswa antara siklus I dan nilai siklus II. Data hasil belajar diperoleh setelah kegiatan tindakan siklus II dengan melakukan evaluasi terhadap siswa.

Berdasarkan hasil evaluasi kegiatan belajar siswa siklus II diperoleh data sebagai berikut.

\section{Perolehan Nilai Siswa Siklus II}

\begin{tabular}{|c|c|c|}
\hline No & Kategori & Nilai \\
\hline 1 & Mean & 81,41 \\
\hline 2 & Median & 80 \\
\hline 3 & Modus & 80 \\
\hline 4 & Nilai Terendah & 70 \\
\hline 5 & Nilai Tertinggi & 95 \\
\hline
\end{tabular}

Sumber: Hasil Evaluasi Siklus II

Berdasarkan tabel diatas, perhitungan hasil belajar siklus II menunjukkan bahwa nilai rata-rata hasil belajar siswa sebesar 81,41 dapat dikatakan berada pada kategori baik.

Distribusi Frekuensi Dan Persentase Hasil Belajar Siswa Siklus II

\begin{tabular}{|c|c|c|c|}
\hline Interval Nilai & Frekuensi (f) & Persen $(\boldsymbol{\&})$ & Kategori \\
\hline $0-40$ & 0 & 0 & Sangat Kurang \\
\hline $41-55$ & 0 & 0 & Kurang \\
\hline $56-70$ & 1 & $3,13 \%$ & Cukup \\
\hline $71-85$ & 29 & $93,74 \%$ & Baik \\
\hline $86-100$ & 1 & $3,13 \%$ & Sangat Baik \\
\hline Jumlah & $\mathbf{3 2}$ & $\mathbf{1 0 0 \%}$ & \\
\hline
\end{tabular}




\section{Diagram Batang Distribusi Frekuensi Dan Persentase Hasil Belajar Siswa Siklus II}

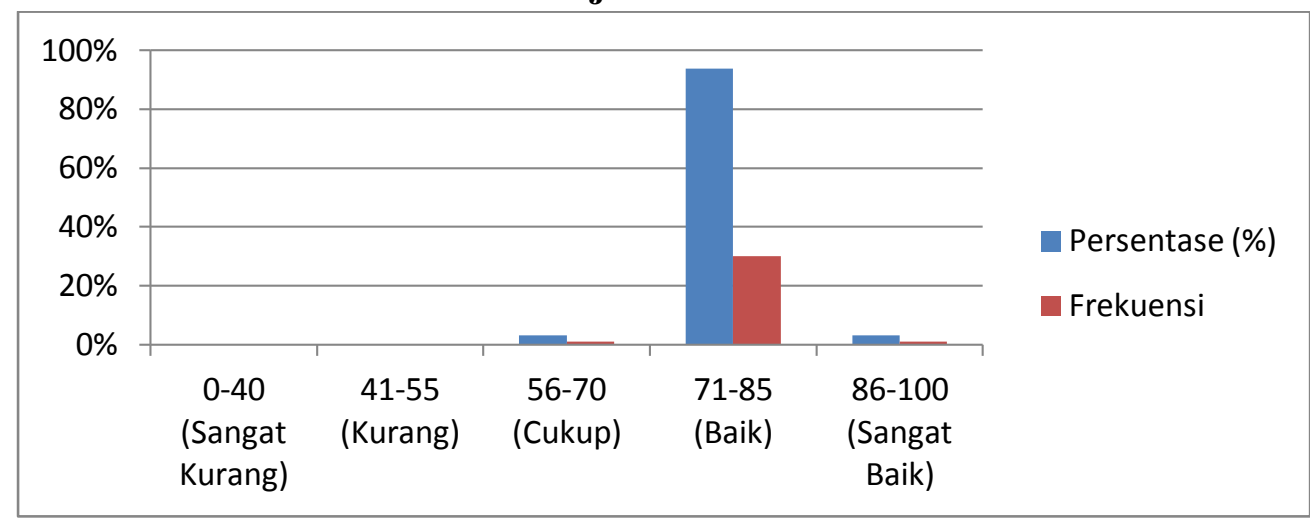

Berdasarkan tabel dan diagram diketahui bahwa tidak ada siswa yang mempunyai nilai dengan kategori sangat kurang dan kurang, 1 siswa $(3,13 \%)$ berada pada kategori cukup, 25 siswa $(93,74 \%)$ berada pada kategori baik dan 1 siswa $(3,13 \%)$ berada pada kategori sangat baik. Nilai rata-rata hasil belajar siswa setelah dilsaksanakan siklus II terjadi peningkatan yaitu 81,41 sudah mencapai nilai kreteria ketuntasan minimal (KKM) yaitu 70.

Ketuntasan Belajar Siswa Siklus II

\begin{tabular}{|c|c|c|c|}
\hline Skor & Katergori & Frekuensi & Persentase (\%) \\
\hline $0-69$ & Tidak Tuntas & 1 & $3.12 \%$ \\
\hline $70-100$ & Tuntas & 31 & 96.88 \\
\hline \multicolumn{2}{|r|}{ Jumlah } & $\mathbf{3 2}$ & $\mathbf{1 0 0}$ \\
\hline
\end{tabular}

Berdasarkan tabel di atas, tentang ketuntasan hasil belajar menunjukkan bahwa 1 siswa yang mendapatkan nilai 0-69 dengan persentase 3.12\% yang tidak tuntas dan sedangkan 31 siswa yang mendapatkan nilai 70-100 dengan persentase 96.88\% yang tuntas. Hal ini berarti bahwa dengan menerapkan model pembelajaran DT2 pada pelajaran sosiologi telah mengalami peningkatan.

Keberhasilan proses pembelajaran pada siklus I dan Siklus II dapat di lihat pada tabel di bawah ini.

Keberhasilan Siklus I dan Siklus II

\begin{tabular}{|l|c|c|c|c|}
\hline \multirow{2}{*}{ Aspek } & \multicolumn{2}{c|}{ Siklus I } & \multicolumn{2}{c|}{ Siklus II } \\
\cline { 2 - 5 } & $\%$ & Kualifikasi & \% & Kualifikasi \\
\hline Guru & $62,67 \%$ & Cukup & $80,44 \%$ & Baik \\
\hline Siswa & $60,89 \%$ & Cukup & $80 \%$ & Baik \\
\hline
\end{tabular}




\begin{tabular}{|l|c|c|c|c|}
\hline $\begin{array}{l}\text { Hasil Belajar Siswa } \\
\text { (Ketuntasan) }\end{array}$ & $62,50 \%$ & Cukup & $96,87 \%$ & Sangat Baik \\
\hline
\end{tabular}

\section{Diagram Persentase Perbandingan Siklus I \& Siklus II}

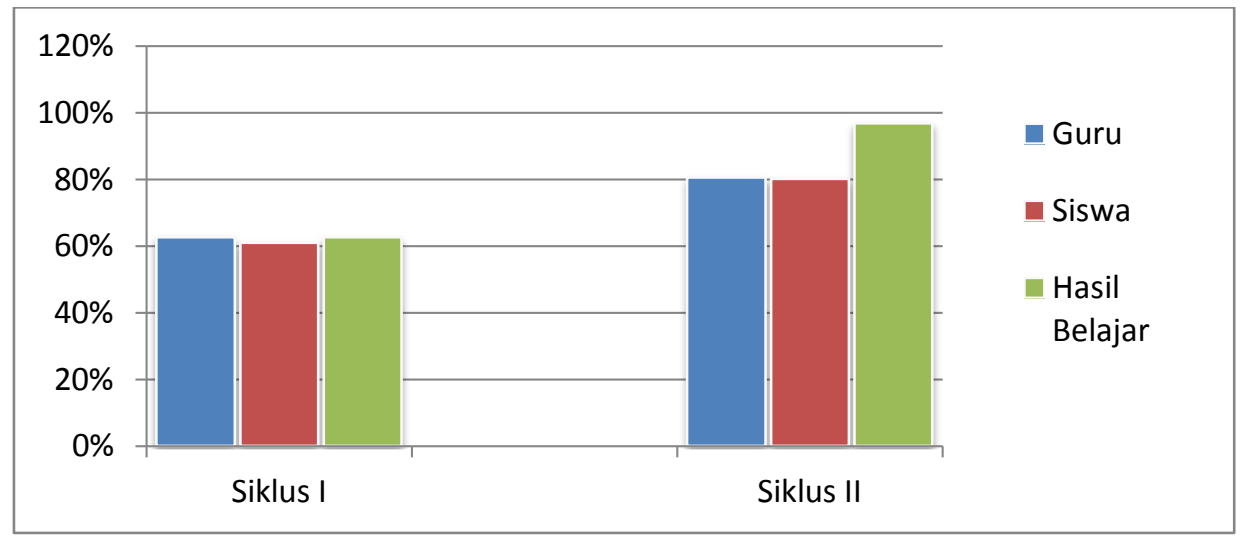

Berdasarkan penjelaskan dan persentase di atas bahwa hasil tes siklus I dan siklus II telah memperoleh peningkatan terhadap hasil belajar sosiologi, yang menunjukkan bahwa hasil belajar siswa (ketuntasan) pada siklus I yaitu 62,50\% dengan kualifikasi cukup dan sedangkan hasil belajar siswa (ketuntasan) pada siklus II yaitu 96,87 \% dengan kualifikasi sangat baik. Maka pada siklus II ini peneliti akan menghentikan penelitian karena sudah terlaksana dengan maksimum. Hal ini berarti bahwa dengan menerapkan model pembelajaran DT2 pada pelajaran sosiologi telah berhasil.

\section{PEMBAHASAN}

Berdasarkan paparan data yang dikemukakan sebelumnya, maka pembahasan difokuskan pada aktifitas guru dan siswa dalam pembelajaran dengan menerapkan model pembelajaran DT2 di kelas XI SMA N 12 Makassar. Pembahasan ini juga berkaitan dengan tahap-tahap model yang digunakan untuk meningkatkan hasil belajar siswa terhadap pembelajaran sosiologi.

Dalam proses pembelajaran siswa merasa senang karena materi yang dipelajari dapat dipahami. Hal ini disebabkan tahap-tahap model yang dilakukan guru saat menyajikan materi sangat menyenangkan, pembelajaran dengan berkelompok membuat siswa terlibat aktif secara keseluruhan dan disela kegiatan pembelajaran guru kadang melontarkan kata-kata humor sehingga siswa tidak merasa bosan dalam belajar. Selain hal tersebut, model pembelajaran yang digunakan guru sangat menunjang keberhasilan 
dalam menyajikan materi. Karena model pembelajaran Dua Tinggal Dua Tamu (DT2) melatih kemampuan para siswa mengemukakan pendapat, berpikir kritis dan memecahkan masalah yang mampu membangkitkan kembali semangat mereka untuk mengikuti pembelajaran karena mereka merasa mendapatkan kepuasannya dalam pembelajaran. Hal ini sesuai dengan pendapat Hamalik (2001: 32) yang menyatakan bahwa belajar akan lebih berhasil jika siswa merasa berhasil dan mendapatkan kepuasannya.

Model pembelajaran yang digunakan melalui tiga tahap, setiap tahap yang dilakukan mempunyai tujuan yang berbeda, sebagaimana yang telah diuraikan pada pelaksanaan tindakan siklus I dan siklus II melalui keaktifkan siswa dalam pembelajaran dengan cara melakukan diskusi dan saling bertukar pendapat dalam pembelajaran membuat siswa merasa terlatih untuk mengolah kemampuan berpikir mereka. Dengan demikian siswa merasa hak mereka sebagai peserta didik terpenuhi dan mendapatkan kepuasan dalam pembelajaran. Hal ini sejalan dengan pendapat Hamalik (2001: 32) yang menyatakan bahwa " belajar akan lebih berhasil jika siswa merasa berhasil dan mendapatkan kepuasannya".

Pada pembelajaran siklus II telah menunjukkan peningkatan pembelajaran yang dimaksimalkan guru sehingga pembelajaran berlangsung dengan baik. Pada tindakan siklus II keberhasilan sudah mencapai target yang diinginkan persentase hasil belajar siswa dapat meningkat dari siklus I hanya mencapai 62,50\% dengan kualifikasi cukup meningkat menjadi 96,87\% dengan kualifikasi sangat baik pada siklus II, ini memberi bukti bahwa guru berhasil membangkitkan minat serta gairah belajar siswa, hal ini dapat terlihat dari kesiapan siswa pada saat mengikuti proses pembelajaran sosiologi, dengan seksama para siswa memperhatikan penjelasan guru. Menurut Hamalik (2001: 33) "Siswa yang telah siap belajar akan dapat melakukan kegiatan belajar lebih mudah dan lebih berhasil”.

Berdasarkan penelitian yang telah dilaksanakan, perolehan hasil belajar sosiologi siswa dari kedua siklus penelitian yang meningkat hingga mencapai indikator keberhasilan yang telah ditetapkan menunjukkan bahwa hasil belajar sosiologi siswa mengalami peningkatan yang signifikan. Penggunaan model pembelajaran Dua Tinggal Dua Tamu (DT2) meningkatkan hasil belajar siswa yang semula rendah, dapat 
meningkat setelah pembelajaran sosiologi dengan menggunakan model pembelajaran DT2.

\section{E. KESIMPULAN DAN SARAN}

1. Kesimpulan

Berdasarkan hasil penelitian dan pembahasan, pada siklus I dan II maka dapat disimpulkan bahwa penerapan model pembelajaran DT2 dapat meningkatkan hasil belajar siswa kelas XI SMAN Negeri 12 Makassar.

Pada pembelajaran ini telah menunjukkan peningkatan pembelajaran yang dimaksimalkan guru sehingga pembelajaran berlangsung dengan baik. Pada tindakan siklus II keberhasilan sudah mencapai target yang diinginkan persentase hasil belajar siswa dapat meningkat dari siklus I hanya mencapai $62,50 \%$ dengan kualifikasi cukup meningkat menjadi 96,87\% dengan kualifikasi sangat baik pada siklus II.

Penerapan model pembelajaran DT2 dapat meningkatkan keaktifan siswa dalam proses belajar mengajar, ini terlihat dari antusias siswa belajar, keaktifan siswa dalam berdiskusi dan proses sosialisasi diantara siswa-siswi berjalan dengan lancar.

2. Saran

Saran yang dapat dimukakan sehubungan dengan hasil penelitian ini yaitu :

a) Sebaiknya untuk menerapkan model pembelajaran Dua Tinggal Dua Tати (DT2) dalam pembelajaran sosiologi guru bisa menyesuaikan materi pembelajaran yang cocok sehingga siswa tidak merasa bosan dan jenuh karena model pembelajaran semakin bervariasi.

b) Guru sebaiknya memberikan kesempatan dan kebebasan kepada siswa untuk berekspresi dan berkreasi dalam proses pembelajaran.

c) Diharapkan kepada tenaga-tenaga pengajar bidang studi khususnya bidang studi sosiologi untuk menerapkan model pembelajaran yang tepat dalam mengajar disetiap pokok bahasan agar tujuan pembelajaran dapat tercapai.

\section{DAFTAR PUSTAKA}

Ahmadi, Abu. 1991. Sosiologi Pendidikan. Jakarta : Rineka Cipta

Arikunto, Suharsimi, Suharjo dan Supardi. 2006. Penelitian Tindakan Kelas. Jakarta : Bumi Aksara 
Arikunto, Suharsimi. 1997. Dasar-dasar Evaluasi Pendidikan. Yogyakarta : Bumi Aksara. 2010. Manajemen Penelitian. Jakarta : Rineka Cipta.

Aunurrahman. 2009. Belajar dan Pembelajaran. Bandung : Alfabeta.

Aqib, Zaenal. 2009. Penelitian Tindakan Kelas. Bandung : Yrama Widya.

Dimyati dan Mudjiono. 2009. Belajar dan Pembelajaran. Jakarta : PT. Rineka Cipta

Daryanto dan Rahardjo Muljo. 2012. Model Pembelajaran Inovatif. Yogyakarta : Gava Media.

Dian, Armanto. 2001. Strategi Belajar Mengajar Sosiologi. Malang : IKIP Malang

Fathurrohman, Pupuh dan Sutikno, M. Sobry. 2011. Strategi Belajar Megajar Melalui Penanaman Konsep Umum \& Konsep Islam. Bandung : PT Refika Aditama

Furchan. 2002. Metodelogi Penelitian Pendidikan. Bandung : Alfabeta

Hamalik, Oemar. 2003. Pendidikan Guru Berdasarkan Pendekatan Kompetensi. Jakarta : Bumi Aksara 2001. Proses Belajar Mengajar. Bandung : Bumi Aksara.

Muslich, Mansur. 2010. Melaksanakan PTK Itu Mudah (Classroom Actio Research). Jakarta : Bumi Aksara.

Narwoko, J. Dwi, dan Bagong Suyanto. 2007. Sosiologi: Teks Pengantar dan Terapan. Jakarta : Kencana.

Nanang Hanafiah \& Cucu Suhana. 2012. Konsep Strategi Pembelajaran. Bandung : PT. Refika Aditama

Paloma, Margaret M. 2010. Sosiologi Kontemporer. Jakarta : Rajawali Pers.

Purwanto. 2011. Evaluasi Hasil Belajar. Yogyakarta : Pustaka Pelajar.

Ritzer, George, dan Douglas J. Goodman. 2003. Teori Sosiologi Modern. Jakarta : Kencana.

Riyanto, Yatim. 2012. Paradigma Baru Pembelajaran: Sebagai Referensi bagi Pendidik dalam Implementasi Pembelajaran yang Efektif dan Berkualitas. Jakarta : Kencana.

Rusman. 2012. Model-Model Pembelajaran: Mengembangkan Profesionalisme Guru. Jakarta : Rajawali Pers. 
Soekanto, Soekanto. 2007. Sosiologi Suatu Pengantar. Jakarta : Raja Grafindo Persada

Sugiyono. 2008. Metode Penelitian Kuantitatif Kualitatif dan R\&D. Bandung : Alfabeta

Suprijono, Agus. 2012. Cooperative Learning Teori dan Aplikasi PAIKEM. Yogyakarta : Pustaka Belajar.

Suryabrata, Sumadi. 2011. Psikologi Pendidikan. Jakarta : Rajawali Pers.

Slameto. 2003. Belajar dan Faktor-faktor yang Mempengaruhi Hasil Belajar. Jakarta : Rineka Cipta.

Sudjana, Nana. 2009. Dasar-dasar Proses Belajar Mengajar. Bandung : Sinar

Sunday (2012). http://ayomengajarindonesia.blogspot.com/2012/12/belajarkelompok.html (diakses tanggal 27 april 2018).

Trianto. 2010. Mendesain Model pembelajaran inovatif-Progresif: Konsep Landasan, dan Implementasinya pada Kurikulum Tingkat Satuan Pendidikan. Jakarta: Kencana.

Tri Bowop. Pembelajaran dalam Pendidikan.http://tribowop.blogspot.co.id/2012/01/model-kooperatif-tipe-two-staytwo.html.diakses pada tanggal 7 februari 2017

Usman H. dan Akbar. 2003. Metodologi Penelitian Sosial. Jakarta : Bumi Aksara 